\title{
Trend Analyses of Parameters of Equations for Minimum Energy Consumption Ratio Achievable in Ubicomp MANETs Using Location-Aware Transmission.
}

\author{
M. Kaleem GALAMALI, Assoc. Prof Nawaz MOHAMUDALLY
}

\begin{abstract}
Research concerning location-tracking, ubicomp functionalities and MANET transmission strategies [35-71] are yielding commendable output. Nevertheless, the area of modelling in ubicomp to assess predictability features, is still at starting points. One particular sub-area is energy considerations in ubicomp coupled by present hardware level of constrained battery power. A prior research was carried out to quantify and model the minimum ratio of energy consumption (Min_R) recordable for a CBR gauged against the energy consumed by the sender, for node densities of 7 until 56 . The corresponding model was observed to be exponential.
\end{abstract}

In this paper, the next level of investigation is laid as as: "What are the trends of variation observable within each parameter of the equations of curves obtained for metric Min_R [19] over varying node densities?"

The need for studying the behaviour of components of an applicable model for metric Min_R and accordingly model the behaviour of each component mathematically remains high since it will involve concerted effort from various researchers. Results obtained will comprehensibly assist designers towards problem solving in ubicomp and provision hardware, software/algorithms support for ubicomp architectures supporting adaptability. This paper is a follow-up of previous research [1-34].

Key terms: Ubicomp- Ubiquitous Computing, MAUCMobile and Ubiquitous Computing, MANET- Mobile Adhoc Network, CBR- Constant Bit Rate, ECR- Energy Consumption Ratio, Min_R- Minimum Ratio.

M. Kaleem GALAMALI,

University of Technology Mauritius (student) Mauritius

Assoc. Prof Nawaz Mohamudally University of Technology Mauritius, Mauritius

\section{Introduction}

A commendable solution to poor resource availability in ubicomp is use of MANETs in which distribution of energy consumption load is performed. This feature is drastically influenced by node density. A past study [19] was aimed at finding the trends observable for metric Min_R for node densities varying between 7 until 56. The model suggested in that paper was the exponential model of the form:
$G(x)=a * \exp (b *(x-0.01))+c$

Here, the equation of the model has involved 3 parameters: $a, b$ and $c$. the successive task that is required in this research for metric Min_R is to derive the mathematical modelling of the parameters of the equation obtained above and formulating the corresponding equations for each parameter.

The key contributions of this paper is the establishment of the trend of variation for each parameter of the equations involved in the model for metric Min_R presented in previous paper [19]. The tabular data in table 1 in that paper [19] covering node numbers 7 until 56 , is re-used here. The mathematical methods produced here may be programmed into software simulators and provide a tool for designers to better understand predictability features in ubicomp and assist in provisioning of future ubicomp needs. The rest of this paper is organised as follows: section 2- Parameter Trend Analysis- Metric Min_R, section 3- Conclusion and References.

\section{Parameter Trend Analysis - Metric ECR.}

2.0 General Procedure Adopted.

The tabulated data for each parameter of equation of model for Min_R is plotted on gnuplot. Graphical analyses using the "fit" command has been undertaken here. Assistance from smooth bezier plot has also been sought. For each graph of parameter plot obtained, the general observations are reported. Here also, various equations of fit are attempted and their corresponding summary report is also reported, for each parameter of metric Min_R. To conclude, choice is made considering value of least reduced chi-square and most acceptable extendability produced at node numbers 80 and 100. Moreover, the values of parameters for each Min_R parameter of equation is noted.

\subsection{Trend Analysis - Min_R parameter " $a$ ".}

The curve obtained shows a rapidly increasing start until a maximum point at node number 21 , followed by a slow decreasing trend. 


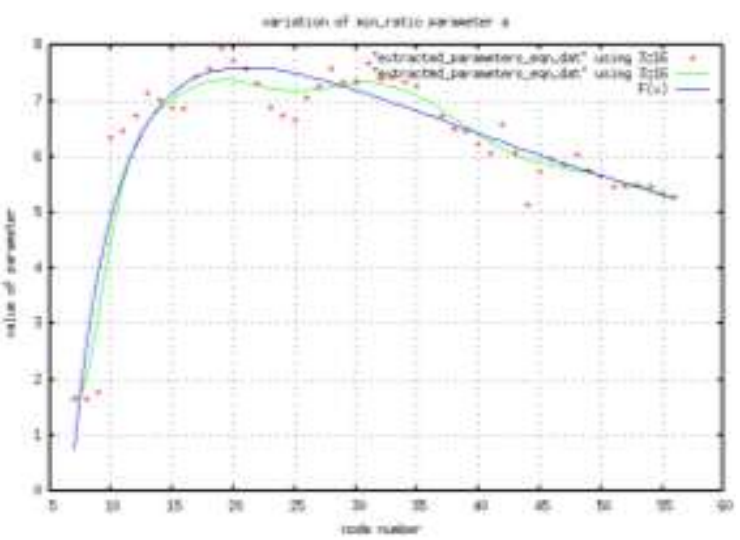

Figure 1: Min_R parameter a

The potentially applicable equations are:

1. $F(x)=\left(\left(a * x^{d}\right) /(\exp ((b * x)+\right.$ C )) $)+f / \log (x)$

Ch_sq $=0.342879 \quad \mathrm{~F}(80)=3.47404148$

$\mathrm{F}(100)=2.232581$

2. $F(x)=\left(\left(a \star x^{d}\right) /(\exp ((b \star x)+\right.$ C ) ) $)+f /(x * \log (x))$

Ch_sq $=0.343979 \quad \mathrm{~F}(80)=3.669129$

$\mathrm{F}(100)=2.714966$

3. $F(x)=\left(\left(a * x^{d}\right) /\left(\exp \left(\left(b * x^{0.7}\right)+c\right.\right.\right.$

)) $+(f / x) * \log (x)$

Ch_sq $=0.343825$

$\mathrm{F}(80)=3.76899$

$\mathrm{F}(100)=2.884475$

4. $F(x)=\left(\left(a * x^{d}\right) /\left(\exp \left(\left(b * x^{h}\right)+c\right)\right)\right)+$

$(f / x) * \log (x)$

Ch_sq $=0.351409 \quad \mathrm{~F}(80)=3.91909$

$\mathrm{F}(100)=3.1378$

\section{Choice of best fit for Min_R Parameter a}

The equation in part 4 above has been selected because of better extendability even if ch_sq is not smallest. The parameters obtained for best fit are:

$a=5.76823, b=17.0628, c=-16.4915, d=3.19163$

, $f=-123.076, h=0.134618$

\subsection{Trend Analysis - Min_R parameter " $b$ ”.}

Generally, a clear linear increasing trend is observed.

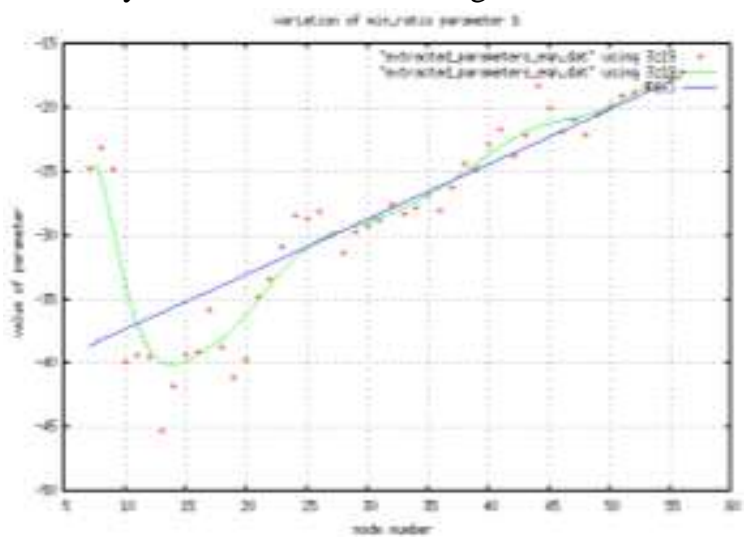

Figure 2: Min_R parameter b
The applicable equation here is

$$
\begin{aligned}
F(x)=d * x & +f \\
& \text { Ch_sq }=20.1303
\end{aligned}
$$

Parameters of best fit are: $d=0.430905, f=-41.6396$

\subsection{Trend Analysis - Min_R parameter " $c$ ".}

Generally, the curve increases at a decreasing rate with a tendency to be flattening.

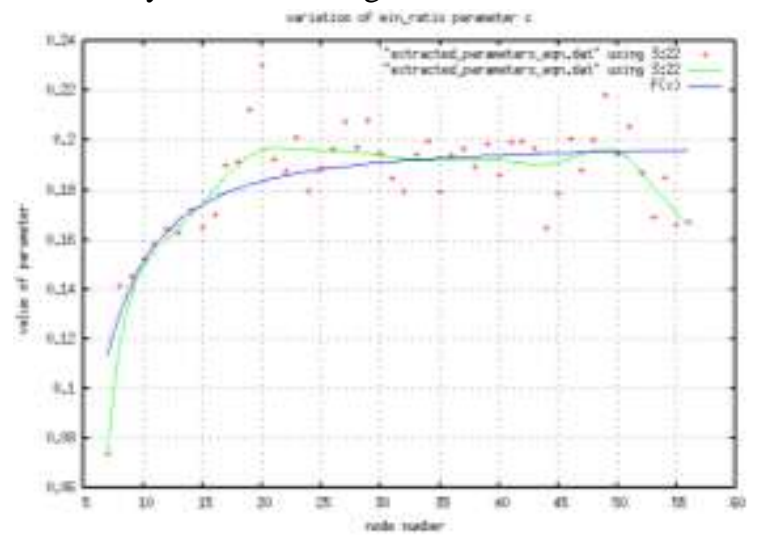

Figure 3: Min_R parameter c

The applicable equation in this situation is:

$$
\begin{aligned}
& \mathrm{F}(\mathrm{x})=(\mathrm{a} / \mathrm{x}) * \exp (\mathrm{b} *(\mathrm{x}+\mathrm{c}))+\left(\mathrm{d} / \mathrm{x}^{1.5}\right)+\mathrm{f} \\
& \text { Ch_sq }=0.000255463 \quad \mathrm{~F}(80)=0.19723859 \\
& \mathrm{~F}(100)=0.197669496
\end{aligned}
$$

The parameters of best fit are:

$\mathrm{a}=0.142437, \mathrm{~b}=-0.00373017, \mathrm{c}=0.09954$,

$\mathrm{d}=-1.93935, \mathrm{f}=0.198628$

\section{Conclusion.}

This piece of research was targeted at and has developed the applicable models of trends of the parameters of equations for the metric Min_R in a MANET topography of $300 \times 300 \mathrm{~m}^{2}$. The models have been derived by refining quite complex mathematical equations. These will certainly assist in studying MANETs for MAUC environment from a software engineering angle, along with formulating computational algorithms to be integrated into simulators for appropriate studies of MANET. The experiment algorithm was run in NS-2 over linux. The plottings and "fit" attempts were practised in gnuplot. Criteria used for evaluating best fit remain smallest reduced chi-square values and smoothest extendability of equations obtained.

Assumptions stated in previous paper [19] are inherited in this paper also. Correctness of gnuplot and its accuracy features are assumed as good.

Further work identified remain: formulating methods of predictability for metric ECR and its trend and 
reporting observations of certain critical values identified.

\section{References}

[1] M. Kaleem GALAMALI, Assoc. Prof Nawaz MOHAMUDALLY, Towards Dependable Pervasive Systems-A Position and Vision Paper, CEET 2014

[2] M. Kaleem GALAMALI, Assoc. Prof Nawaz MOHAMUDALLY, Model of Energy Savings achievable with Location-aware Node-to-Node Transmission in UbiComp , CEET 2014

[3] M. Kaleem GALAMALI, Assoc. Prof Nawaz MOHAMUDALLY, Model of Energy Savings achievable with Location-aware Node-to-Node Transmission in UbiComp Using Location Refresh Intervals, CEET 2014

[4] M. Kaleem GALAMALI, Assoc. Prof Nawaz MOHAMUDALLY, Model of Energy Savings achievable with Location-aware Transmission in UbiComp Using Relays, CEET 2014

[5] M. Kaleem GALAMALI, Assoc. Prof Nawaz MOHAMUDALLY, Mathematical modeling of need of exact number of relays to ensure seamless mobility in mobile computing, CEET 2014

[6] M. Kaleem GALAMALI, Assoc. Prof Nawaz MOHAMUDALLY, Modelling of need for multiple relays for ensuring seamless mobility, CEET 2014

[7] M. Kaleem GALAMALI, Assoc. Prof Nawaz MOHAMUDALLY, Investigation of prominence of placements of relays in a ubicomp topography,

[8] M. Kaleem GALAMALI, Assoc. Prof Nawaz MOHAMUDALLY, Model of energy savings achievable with location-aware transmission in ubicomp using optimised number of relays.

[9] M. Kaleem GALAMALI, Assoc. Prof Nawaz MOHAMUDALLY, Investigation of Prominence of Placements of Optimised Number of Relays in a Ubicomp Topography using Location-Aware Transmission, CEET 2015.

[10] M. Kaleem GALAMALI, Assoc. Prof Nawaz MOHAMUDALLY, Extending Node Battery Availability in Ubicomp with Location-Aware Transmission, CEET 2015.

[11] M. Kaleem GALAMALI, Assoc. Prof Nawaz MOHAMUDALLY, Extending Node Battery Availability in Ubicomp with Location-Aware Transmission using Location Refresh Intervals, CEET 2015.

[12] M. Kaleem GALAMALI, Assoc. Prof Nawaz MOHAMUDALLY, Extending Node Battery Availability in Ubicomp with Location-Aware Transmission using Uniformly Placed Relays, CEET 2015.

[13] M. Kaleem GALAMALI, Assoc. Prof Nawaz MOHAMUDALLY, Extending Node Battery Availability in Ubicomp with Location-Aware Transmission Using Optimally Placed Relays, CEET 2015.

[14] M. Kaleem GALAMALI, Assoc. Prof Nawaz MOHAMUDALLY, Model of Sender Node Energy Savings Achievable with Location-Aware MANET Transmission in Ubicomp. ACCN 2016

[15] M. Kaleem GALAMALI, Assoc. Prof Nawaz MOHAMUDALLY, Model of Overall Node Energy Savings Achievable with Location-Aware MANET Transmission in Ubicomp. ACCN 2016

[16] M. Kaleem GALAMALI, Assoc. Prof Nawaz MOHAMUDALLY, Model of Sender Node Extra Energy Savings Achievable in MANET Against Direct Node-toNode Transmission Using Location-Aware Transmission in Ubicomp. ACCN 2016

[17] M. Kaleem GALAMALI, Assoc. Prof Nawaz MOHAMUDALLY, Model of Overall Node Extra Energy Savings Achievable in MANET against Direct Node-toNode Transmission Using Location-Aware Transmission in Ubicomp. ACCN 2016

[18] M. Kaleem GALAMALI, Assoc. Prof Nawaz MOHAMUDALLY, Model of Energy Consumption Ratio
Achievable in MANET Using Location-Aware Transmission in Ubicomp. ACCN 2016

[19] M. Kaleem GALAMALI, Assoc. Prof Nawaz MOHAMUDALLY, Model of Minimum Energy Consumption Ratio Achievable in MANET Using LocationAware Transmission in Ubicomp. ACCN 2016

[20] M. Kaleem GALAMALI, Assoc. Prof Nawaz MOHAMUDALLY, Model of Maximum Energy Consumption Ratio Achievable in MANET Using LocationAware Transmission in Ubicomp. ACCN 2016

[21] M. Kaleem GALAMALI, Assoc. Prof Nawaz MOHAMUDALLY, Model of Overall Energy Consumption Fairness Ratio Achievable in MANET Using LocationAware Transmission in Ubicomp. ACCN 2016

[22] M. Kaleem GALAMALI, Assoc. Prof Nawaz MOHAMUDALLY, Model of Overall Energy Consumption Fairness Proportion Achievable in MANET Using LocationAware Transmission for Ubicomp, CEET 2016

[23] M. Kaleem GALAMALI, Assoc. Prof Nawaz MOHAMUDALLY, Model of Minimum Fairness Proportion Achievable in MANET Using Location-Aware Transmission for Ubicomp, CEET 2016

[24] M. Kaleem GALAMALI, Assoc. Prof Nawaz MOHAMUDALLY, Model of Maximum Fairness Proportion Achievable in MANET Using Location-Aware Transmission for Ubicomp, CEET 2016

[25] M. Kaleem GALAMALI, Assoc. Prof Nawaz MOHAMUDALLY, Model of Sender Fairness Proportion Achievable in MANET Using Location-Aware Transmission for Ubicomp, CEET 2016

[26] M. Kaleem GALAMALI, Assoc. Prof Nawaz MOHAMUDALLY, Model of Distance Travelled by packets in MANETs using Location-Aware Transmission for Ubicomp, CEET 2016

[27] M. Kaleem GALAMALI, Assoc. Prof Nawaz MOHAMUDALLY, Model of Maximum CBR Distance Travelled by packets in MANETs using Location-Aware Transmission for Ubicomp, CEET 2016

[28] M. Kaleem GALAMALI, Assoc. Prof Nawaz MOHAMUDALLY, Model of Minimum CBR Distance Travelled by packets in MANETs using Location-Aware Transmission for Ubicomp, CEET 2016

[29] M. Kaleem GALAMALI, Assoc. Prof Nawaz MOHAMUDALLY, Model of Range CBR Distance Experienced by Transmissions in MANETs using LocationAware Transmission for Ubicomp, CEET 2016

[30] M. Kaleem GALAMALI, Assoc. Prof Nawaz MOHAMUDALLY, Trend Analyses of Parameters of Equations for Sender Node Energy Savings Achievable in ubicomp MANETs using Location-Aware Transmission, ACCN 2017.

[31] M. Kaleem GALAMALI, Assoc. Prof Nawaz MOHAMUDALLY, Trend Analyses of Parameters of Equations for Overall Node Energy Savings Achievable in ubicomp MANETs using Location-Aware Transmission, ACCN 2017.

[32] M. Kaleem GALAMALI, Assoc. Prof Nawaz MOHAMUDALLY, Trend Analyses of Parameters of Equations for Sender Node Extra Energy Savings Achievable in MANET against Direct Node-to-Node Location-Aware Transmission, ACCN 2017.

[33] M. Kaleem GALAMALI, Assoc. Prof Nawaz MOHAMUDALLY, Trend Analyses of Parameters of Equations for Overall Nodes Extra Energy Savings Achievable in MANET against Direct Node-to-Node Location-Aware Transmission, ACCN 2017.

[34] M. Kaleem GALAMALI, Assoc. Prof Nawaz MOHAMUDALLY, Trend Analyses of Parameters of Equations for Energy Consumption Ratio Achievable in Ubicomp MANET Using Location-Aware Transmission, ACCN 2017.

[35] Markus Bylund and Zary Segall, Towards seamless mobility with personal servers, 2004

[36] Masugi Inoue, Mikio Hasegawa, Nobuo Ryoki and Hiroyuk Morikawa, Context-Based Seamless Network and Application Control, 2004

[37] Xiang Song, Umakishore Ramachandran, MobiGo: A Middleware for Seamless Mobility, College of Computing 
Georgia Institute of Technology, Atlanta, GA, USA, August 2007

[38] Budzisz, Ferrús, R., Brunstrom A., Grinnemo, K, Fracchia, R., Galante, G., and Casadevall, F. Towards transport-layer mobility: Evolution of SCTP multihoming, March 2008

[39] Paul Dourish \& Genevieve Bell, Divining a digital future, 2011.

[40] Xiang Song, Seamless Mobility In Ubiquitous Computing Environments, $\mathrm{PhD}$ Thesis, Georgia Institute of Technology, August 2008

[41] Kevin O Mahony, Jian Liang, Kieran Delaney, User-Centric Personalization and Autonomous Reconfiguration Across Ubiquitous Computing Environments, NIMBUS Centre Cork Institute of Technology, Cork, Ireland, UBICOMM 2012

[42] Pablo Vidales, Seamless mobility in 4G systems, Technical Report, University of Cambridge, Computer Laboratory, Number 656, November 2005

[43] João Pedro Sousa and David Garlan, Aura: An Architectural Framework for User Mobility in Ubiquitous Computing Environments, School of Computer Science, Carnegie Mellon University, USA, August 2002

[44] Dennis Lupiana, Ciaran O’Driscoll, Fredrick Mtenzi, Defining Smart Space in the Context of Ubiquitous Computing, Dublin Institute of Technology, Ireland, Special Issue on ICIT 2009 Conference - Web and Agent Systems, 2009

[45] N.S.V.Shet1, Prof.K.Chandrasekaran2 and Prof. K.C.Shet3, WAP Based Seamless Roaming In Urban Environment with Wise Handoff Technique, International Journal of UbiComp (IJU), Vol.1, No.4, October 2010

[46] Yipeng Yu Dan He Weidong Hua Shijian Li Yu Qi Yueming Wang Gang Pan, FlyingBuddy2: A Braincontrolled Assistant for the Handicapped, Zhejiang University, UbiComp'12, September 5-8, 2012.

[47] Jing Su, James Scott, Pan Hui, Jon Crowcroft, Eyal de Lara Christophe Diot, Ashvin Goel, Meng How Lim, and Eben Upton, Haggle: Seamless Networking for Mobile Applications, 2007

[48] Rui Han, Moustafa M. Ghanem, Li Guo, Yike Guo*, Michelle Osmond, Enabling cost-aware and adaptive elasticity of multi-tier cloud applications, Future Generation Computer Systems, 2012

[49] Byrav Ramamurthy, K. K. Ramakrishnan, Rakesh K. Sinha, Cost and Reliability Considerations in Designing the NextGeneration IP over WDM Backbone Networks, 2012.

[50] Bhavish Aggarwal, Aditya Akella, Ashok Anand, Athula Balachandran, Pushkar Chitnis, Chitra Muthukrishnan, Ram Ramjee and George Varghese, EndRE: An End-System Redundancy Elimination Service for Enterprises, NSDI 2010, San Jose, CA

[51] Ashok Anand, Vyas Sekar and Aditya Akella, SmartRE: An Architecture for Coordinated Network-wide Redundancy Elimination, SIGCOMM 2009, Barcelona, Spain

[52] John Breeden II, "Smart-phone battery life could double without better batteries", Nov 14, 2012

[53] Andy Boxall, "When will your phone battery last as long as your kindle", December 5, 2012.

[54] Imielinski, T. and Navas, J.C. (1999). GPS-based geographic addressing, routing, and resource discovery. Comms. ACM, Vol. 42, No. 4, pp. 86-92.

[55] Hightower, J. and Borriello, G. (2001). Location Systems for Ubiquitous Computing. IEEE Computer, Vol. 34, No. 8, August, pp. 57-66.

[56] Harter, A., Hopper, A., Steggles, P., Ward, A. and Webster, P. (2002). The Anatomy of a Context-Aware Application. Wireless Networks, Vol. 8, No. 2-3, Mar-May, pp. 187-197.

[57] Hightower, J., Brumitt, B. and Borriello, G. (2002). The Location Stack: A Layered Model for Location in Ubiquitous Computing. Proceedings of the 4th IEEE Workshop on Mobile Computing Systems \& Applications (WMCSA 2002), Callicoon, NY, USA, June, pp. 22-28.

[58] Graumann, D., Lara, W., Hightower, J. and Borriello, G. (2003). Real-world implementation of the Location Stack: The Universal Location Framework. Proceedings of the 5th IEEE Workshop on Mobile Computing Systems \&
Applications (WMCSA 2003), Monterey, CA, USA, October, pp. 122-128.

[59] Ko, Y., \& Vaidya, N. H. (2000). Location-aided routing (LAR) in mobile ad hoc networks. Wireless Networks, 6(4), 307-321.

[60] Liao, W.-H., Tseng, Y.-C., \& Sheu, J.-P. (2001). GRID: a fully location-aware routing protocol for mobile ad hoc networks. Telecommunication Systems, 18(1), 37-60.

[61] Kuhn, F., Wattenhofer, R., Zhang, Y., \& Zollinger, A. (2003). Geometric ad-hoc routing: of theory and practice. In Proceedings of the ACM (PODC'03) (pp. 63-72).

[62] Jiang, X., \& Camp, T. (2002). Review of geocasting protocols for a mobile ad hoc network. In Proceedings of the Grace Hopper Celebration (GHC).

[63] Ko, Y. \& Vaidya, N. H. (1999). Geocasting in mobile ad hoc networks: location-based multicast algorithms. In Proceedings of the IEEE (WMCSA'99) (pp. 101).

[64] Mauve, M., Fuler, H., Widmer, J., \& Lang, T. (2003) Position-based multicast routing for mobile ad-hoc networks (Technical Report TR-03-004). Department of Computer Science, University of Mannheim.

[65] Xu, Y., Heidemann, J., \& Estrin, D. (2001). Geographyinformed energy conservation for adhoc routing. In Proceedings of the ACM/IEEE (MOBICOM'01) (pp. 70-84).

[66] Hu, Y.-C., Perrig, A., \& Johnson, D. (2003). Packet leashes: a defense against wormhole attacks in wireless ad hoc networks. In Proceedings of the INFOCOM' 03 (pp. 19761986).

[67] Patwari, N., Hero III, A. O., Perkins, M., Correal, N. S., \& O’Dea, R. J. (2003). Relative location estimation in wireless sensor networks. IEEE Transactions on Signal Processing, 51(8), 2137-2148.

[68] Baldauf, M., Dustdar, S., \& Rosenberg, F. (2007). A Survey on Context Aware Systems. International Journal of Ad Hoc and Ubiquitous Computing, Inderscience Publishers. forthcoming. Pre-print from: http://www.vitalab.tuwien.ac.at/ florian/papers/ijahuc2007.pdf

[69] Hong, D., Chiu, D.K.W., \& Shen, V.Y. (2005). Requirements elicitation for the design of context-aware applications in a ubiquitous environment. In Proceedings of ICEC'05 (pp. 590-596)

[70] Neeraj Tantubay, Dinesh Ratan Gautam and Mukesh Kumar Dhariwal, A Review of Power Conservation in Wireless Mobile Ad hoc Network (MANET)", International Journal of computer Science Issues, Vol 8, Issue 4, No 1, July 2011.

[71] Wenrui Zhao, Mostafa Ammar and Ellen Zegura, "A Message Ferrying Approach for Data Delivery in Sparse Mobile Ad Hoc Networks", MobiHoc'04, May 24-26, 2004, Roppongi, Japan.

About Author (s):

Associate Professor Nawaz Mohamudally works at University of Technology, Mauritius (UTM) and has undertaken supervision of MPhil/PhD Students for many years.

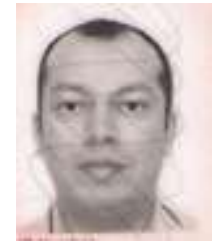

M. Kaleem Galamali is a part-time student (achieved M Phil Transfer on 28.10.2014, currently $\mathrm{PhD}$ student) at UTM under supervision of A.P. Nawaz Mohamudally. 